\title{
Efek Ekstrak Kacang Tunggak terhadap Osteoblas dan Osteoklas pada Tikus dengan Ovarektomi
}

\section{The Effect of Blackeyed Peas on Osteoblast and Osteoclast of Rat with Ovarectomy}

\author{
Didiek Darmadi $T^{1}$, Nurdiana ${ }^{2}$, Eviana Norahmawati ${ }^{3}$ \\ ${ }^{1}$ Program Studi Pendidikan Dokter Fakultas Kedokteran Universitas Brawijaya Malang \\ ${ }^{2}$ Laboratorium Farmakologi Fakultas Kedokteran Universitas Brawijaya Malang \\ ${ }^{3}$ Laboratorium Patologi Anatomi Fakultas Kedokteran Universitas Brawijaya Malang
}

\begin{abstract}
ABSTRAK
Setelah menopause, wanita kehilangan efek protektif dari estrogen, sehingga merubah jalannya remodeling tulang dan akhirnya terjadi osteoporosis. Tujuan penelitian ini untuk mengetahui apakah ekstrak kacang tunggak dengan kandungan genistein didalamnya dapat berperan sebagai fitoestrogen yang dapat menjadi alternatif terapi pengganti estrogen pada tikus yang telah diovarektomi. Pada penelitian ini digunakan 6 kelompok yaitu: 1) kelompok tikus normal (K-neg), 2) kelompok tikus yang di ovarektomi dan dipertahankan selama 1 bulan (K-pos1), 3) kelompok tikus yang di ovarektomi dan dipertahankan selama 2 bulan (K-pos2), 4) kelompok yang diovarektomi dan dipertahankan selama 1 bulan kemudian diberi ekstrak kacang tunggak dosis 0,5 ml/kgBB (K-1), 5) 2,5 ml/kgBB (K-2), dan kelompok 6 dengan dosis $5 \mathrm{ml} / \mathrm{kgBB}(\mathrm{K}-3)$. Tulang femur distal setiap tikus diambil kemudian dicat menggunakan Hematoxillin-Eosin. Jumlah osteoblas dan osteoklas kemudian dihitung dari 20 lapang pandang dengan perbesaran 1000x menggunakan mikroskop mikrofoto Olympus dan kemudian dihitung rata-ratanya. Data dianalisa menggunakan One Way ANOVA. Hasil menunjukkan jumlah osteoblas pada pada kelompok tikus yang di ovorektomi selama satu bulan dengan pemberian ekstrak kacang tunggak dosis 2,5 dan $5 \mathrm{ml} / \mathrm{kgBB}$ secara signifikan lebih rendah dibandingkan kontrol positif. Pemberian ekstrak kacang tunggak pada tikus yang diovorektomi juga memberikan kadar osteoklas yang lebih tinggi dbandingkan kontrol positif. Pemberian ekstrak kacang tunggak dapat meningkatkan jumlah osteoblas dan menurunkan jumlah osteoklas pada tikus yang mengalami perlakuan ovarektomi.
\end{abstract}

Kata Kunci: Kacang tunggak, osteoblas, osteoklas, osteoporosis

\begin{abstract}
After menopause, women loss the protective effect of estrogen, so that process of bone remodelling is altered and osteoporosis begins. This study investigas whether genistein in blackeyed peas extract can act as phytoestrogen and become estrogen-replacement-therapy alternative in ovariectomized rats. In this study, there were 6 groups: the first group is normal control rats (K-neg), the second group is ovariectomized rats which are kept alive for 1 month (K-pos 1$)$, the third group is ovariectomized rats which are kept alive for 2 month (K-pos 2), the fourth group is ovariectomized rats which are kept alive for 1 month and given blackeyed peas extract $0,5 \mathrm{ml} / \mathrm{kgBW}(\mathrm{K}-1)$, the fifth group with dosage 2,5 $\mathrm{ml} / \mathrm{kgBW}(\mathrm{K}$ 2), and the sixth group with dosage $5 \mathrm{ml} / \mathrm{kgBW}(\mathrm{K}-3)$. Distal femoral bone of each rat was taken and stained using Hematoxillin-Eosin. The quantity of osteoblast and osteoclast were counted from 20 visual fields with 1000x magnitude using Microphoto Microscope Olympus and then averaged out. Data was analized using One Way ANOVA. The average quantity of osteoblast and osteoclast was significant up higher in $K-1$ and $K-2$ compared to $K$-pos 2 . The average quantity of osteoclast was significant up lower in $K-1, K-2$, and $K-3$ compare to $K$-pos2. It can be concluded that blackeyed peas extract can increase the quantity of osteoblast and decrease the quantity of osteoclast in the ovariectomized rats.
\end{abstract}

Keywords: Blackeyed pea, genistein, ovariectomy, osteoporosis, osteoblast, osteoclast, phytoestrogen

Jurnal Kedokteran Brawijaya, Vol. 26, No.3 Februari 2011; Korespondensi: Nurdiana. Laboratorium Farmakologi Fakultas Kedokteran Universitas Brawijaya Malang, JI Veteran Malang Tel. (0341)569117Email: nurdianafarmako@yahoo.com 


\section{PENDAHULUAN}

Menopause adalah bagian dari proses penuaan yang melibatkan sistem reproduksi wanita yang umum dialami oleh semua wanita (1). Menopause lebih cepat dicapai wanita Indonesia pada usia 48 tahun dibandingkan wanita barat, yaitu usia 60 tahun (2). Pada proses penuaan terjadi berbagai perubahan dalam tubuh, tak terkecuali organorgan reproduksi. Organ-organ seperti uterus, tuba falopii, dan ovarium pun mengalami proses penuaan. Proses ini akan menyebabkan organ-organ reproduksi tersebut mengalami kemunduran fungsi.

Fungsi ovarium yang terganggu mengakibatkan kehilangan kemampuan dalam produksi estrogen sehingga terjadi perubahan pola haid. Haid menjadi tidak teratur, semakin jarang, dan pada akhirnya akan berhenti. Proses henti inilah yang disebut menopause, tetapi tidak terdapat batasan yang jelas kapan haid ini berhenti. Seseorang baru dikatakan telah mengalami menopause jika setahun sudah tidak mendapatkan haid. Akibat dari penurunan produksi hormon estrogen ini akan menyebabkan seseorang mengalami gejala-gejala, yaitu semburat panas atau yang dikenal dengan hot flushes, depresi, gangguan fungsi seksual, osteoporosis, dan penyakit jantung koroner (3).

Masalah menopause sudah ada sejak manusia pertama ada, tetapi karena usia harapan hidup wanita meningkat maka masalah menopause ini semakin bertambah. Tahun 2000, usia harapan hidup wanita mencapai 80 tahun (3). Pada masa menopause dan post-menopause, produksi hormon estrogen menurun, mengakibatkan kehilangan bahan-bahan tulang sehingga terjadi osteoporosis. Menurut World Health Organization (WHO) osteoporosis adalah penyakit yang ditandai dengan rendahnya massa tulang dan memburuknya mikrostruktural jaringan tulang, yang menyebabkan kerapuhan tulang sehingga meningkatkan risiko terjadinya fraktur. Osteoporosis tidak memberikan keluhan klinis, kecuali apabila telah terjadi fraktur. Fraktur paling sering terjadi pada pergelangan tangan, tulang belakang, serta pinggang, tetapi semua tulang bisa juga mengalaminya. Osteoporosis dapat terjadi pada wanita maupun pria. Delapan puluh persen osteoporosis terjadi pada wanita atau dengan perbandingan $6: 1$. Wanita yang terkena bisa usia tua atau wanita usia muda yang mengalami penghentian siklus menstruasi (2).

Oleh karena masalah menopause dan akibat-akibat yang ditimbulkan, dikembangkan suatu terapi hormon estrogen, yaitu Hormone Replacement Therapy (HRT). Estrogen adalah hormon yang mempengaruhi fisiologi pria dan wanita. Oleh karena itu, jumlah yang paling besar dari estrogen reseptor (ER) ditemukan di jaringan yang berhubungan dengan reproduksi. Seperti kelenjar mammae, ovarium, vagina dan uterus. Pada pria, reseptor estrogen dapat ditemukan di epididimis dan prostat. ada pula aksi dari estrogen pada otak, tulang, sistem kardiovaskular, ginjal, sistem imun dan liver (4). Kajian menunjukkan bahwa pemberian hormon estrogen, khususnya sintetik atau buatan membawa efek lain yang cukup mengkawatirkan, yaitu kanker endometrium atau selaput lendir rahim dan kanker payudara (5).
Kelemahan HRT mendorong perlunya alternatif terapi osteoporosis yang mempunya efek samping yang lebih minimal sehingga selain dapat mengurangi gejala menopause juga dapat meningkatkan kualitas hidup perempuan post-menopause, yaitu dengan menggunakan fitoestrogen. Fitoestrogen adalah substansi derivat dari tanaman yang secara struktur maupun fungsional sama seperti estradiol $(6,7)$. Khasiat estrogenik terjadi karena fitoestrogen juga memiliki 2 gugus - $\mathrm{OH}$ atau hidroksil yang berjarak 1,0-11,5 $\mathrm{A}^{\circ}$ pada intinya, sama persis dengan inti estrogen sendiri. Para peneliti telah sepakat bahwa jarak $11 \mathrm{~A}^{\circ}$ dan gugus $-\mathrm{OH}$ inilah yang menjadi struktur pokok suatu substrat agar mempunyai efek estrogenik, yakni memiliki afinitas tertentu untuk dapat "menduduki" estrogen receptors. Substrat-substrat tersebut baru akan berefek estrogenik apabila telah berikatan dengan reseptor-reseptor estrogen tersebut. Senyawa-senyawa tersebut antara lain, isoflavones, Lignans, Coumestans, dan Tripterpene glycosides (5).

Salah satu tanaman yang terbukti memiliki kandungan fitoestrogen (genistein dan daidzein) adalah kacang tunggak, tanaman ini tumbuh secara meluas di tanah air sehingga sangat dimungkinkan untuk diolah dan dikelola sebagai produk komersial untuk pengobatan menopause (5). Dan juga hasil identifikasi komponen isoflavon menggunakan high performance liquid chromatography (HPLC) didapatkan konsentrasi genistein dan daidzein dari kacang tunggak lebih tinggi dari kedelai lokal (8). Berdasar teori dan fakta-fakta diatas perlu dibuktikan apakah kandungan fitoestrogen didalam ekstrak kacang tunggak tersebut dapat mencegah terjadinya osteoporosis dengan cara melihat jumlah osteoblas dan osteoklas.

\section{METODE}

Penelitian dilakukan dengan rancangan eksperimen sederhana (post test control group design). Hewan coba dibagi menjadi 6 kelompok perlakuan yang masing-masing kelompok terdiri dari 4 tikus secara random. Kelompok pertama adalah tikus normal (kontrol negatif), kelompok kedua adalah tikus yang diovarektomi dan dipertahankan selama 1 bulan (kontrol positif 1), kelompok ketiga adalah tikus yang diovarektomi dan dipertahankan selama 2 bulan (kontrol positif 2), kelompok keempat (K-1 adalah tikus yang diovarektomi dan dipertahankan selama 1 bulan dan diberi ekstrak kacang tunggak dosis I $(0,5$ $\mathrm{ml} / \mathrm{kgBB})$, kelompok kelima (K-2) adalah tikus yang diovarektomi dan dipertahankan selama 1 bulan dan diberi ekstrak kacang tunggak dosis II (2,5 ml/kgBB), dan kelompok keenam (K-3) adalah tikus yang diovarektomi dan dipertahankan selama 1 bulan dan diberi ekstrak kacang tunggak dosis III (5 ml/kgBB). Ovarektomi dilakukan untuk memberikan efek seperti menopause dimana kadar estrogen menjadi sangat rendah, sehingga jumlah osteoblas akan menurun dan jumlah osteoklas akan meningkat. Masing-masing tikus dari tiap kelompok diambil femurnya dan dibuat preparat histopatologis dengan pengecatan Hematoxillin-Eosin (HE), setelah itu dihitung jumlah osteoblas dan osteoklas pada mikroskop mikrofoto Olympus BX51 dan kamera universal DP71 dengan perbesaran $1000 x$ pada masing-masing kelompok. 


\section{HASIL}
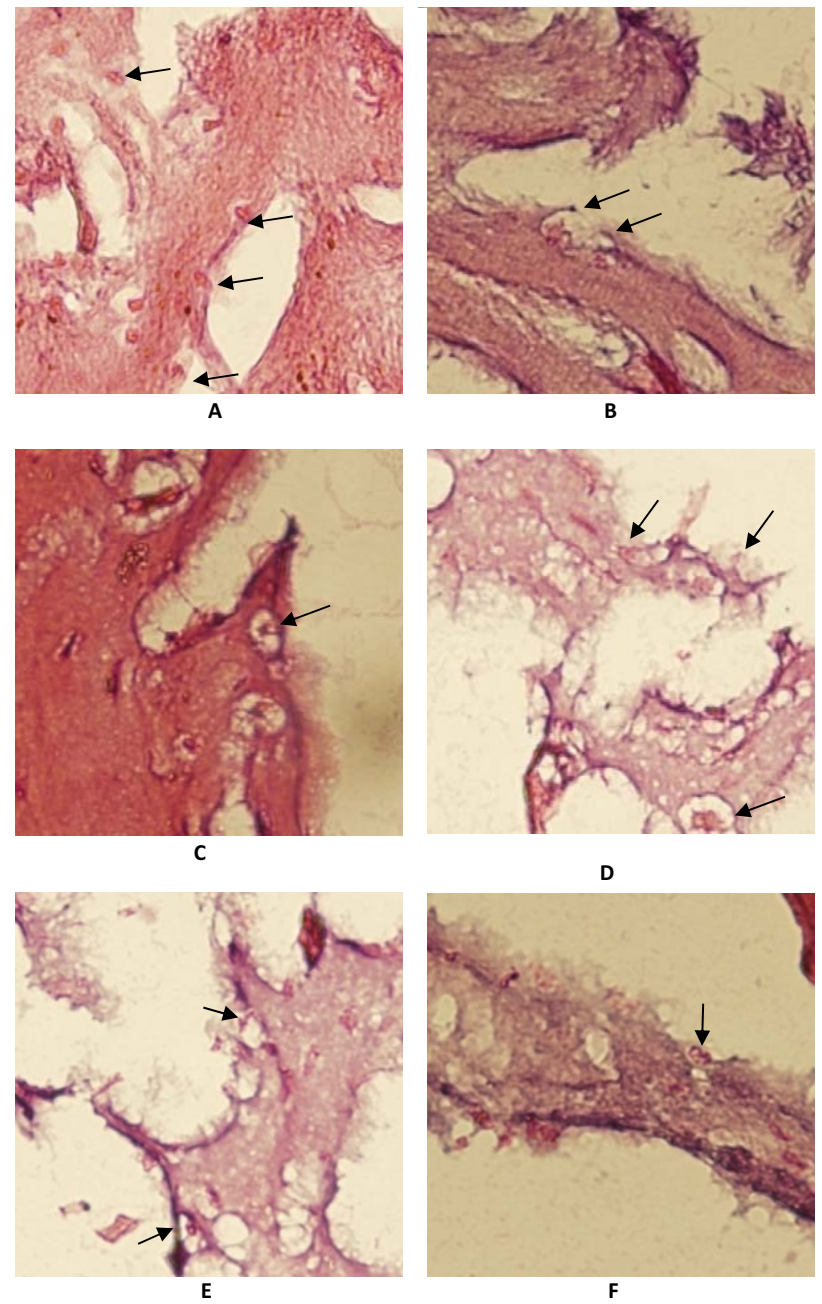

Gambar 1. Gambaran histologis perubahan jumlah osteoblas antar kelompok perlakuan

Keterangan: Tanda panah menunjukkan sel osteoblast

A. (K-neg): kelompok tikus normal

B. (K-pos1): kelompok tikus diovarektomi dan dipertahankan selama 1 bulan

C. (K-pos2): kelompok tikus diovarektomi dan dipertahankan selama 2 bulan

D. (K-1): kelompok tikus diovarektomi dan dipertahankan selama 1 bulan + ekstrak kacang tunggak dosis $0,5 \mathrm{ml} / \mathrm{kgBB}$

E. (K-2): kelompok tikus diovarektomi dan dipertahankan selama 1 bulan + ekstrak kacang tunggak dosis $2,5 \mathrm{ml} / \mathrm{kgBB}$

F. (K-3): kelompok tikus diovarektomi dan dipertahankan selama 1 bulan + ekstrak kacang tunggak dosis $5 \mathrm{ml} / \mathrm{kgBB}$

Data disajikan secara kualitatif untuk menunjukkan gambaran perubahan jumlah osteoklas dan osteoblas pada masing-masing kelompok perlakuan, kemudian dihitung jumlah osteoblas dan osteoklas. Gambar 1 menunjukkan perubahan jumlah osteoblas antar kelompok perlakuan. Tampak gambaran osteoblas pada kondisi normal yang lebih banyak dibandingkan sesudah ovarektomi 1 dan 2 bulan. Gambaran osteblast menjadi membaik meskipun belum sama dengan normal. Gambaran serupa juga didapatkan pada jumlah osteoklas, pada saat pemberian ekstrak kacang tunggak.

Secara kualitatif Gambar 2 menunjukkan perubahan jumlah osteoklast sesudah overektomi dan pemberian

ekstrak kacang tunggak berbagai dosis. Perlakuan overektomi (Gambar 2B) tampak memberikan gambaran jumlah osteoklast yang lebih banyak dibanding normal. Pemberian ekstrak kacang tunggak (CDEF) memberikan gambaran jelas osteoklast yang lebih rendah dibanding sesudah ovarektomi.
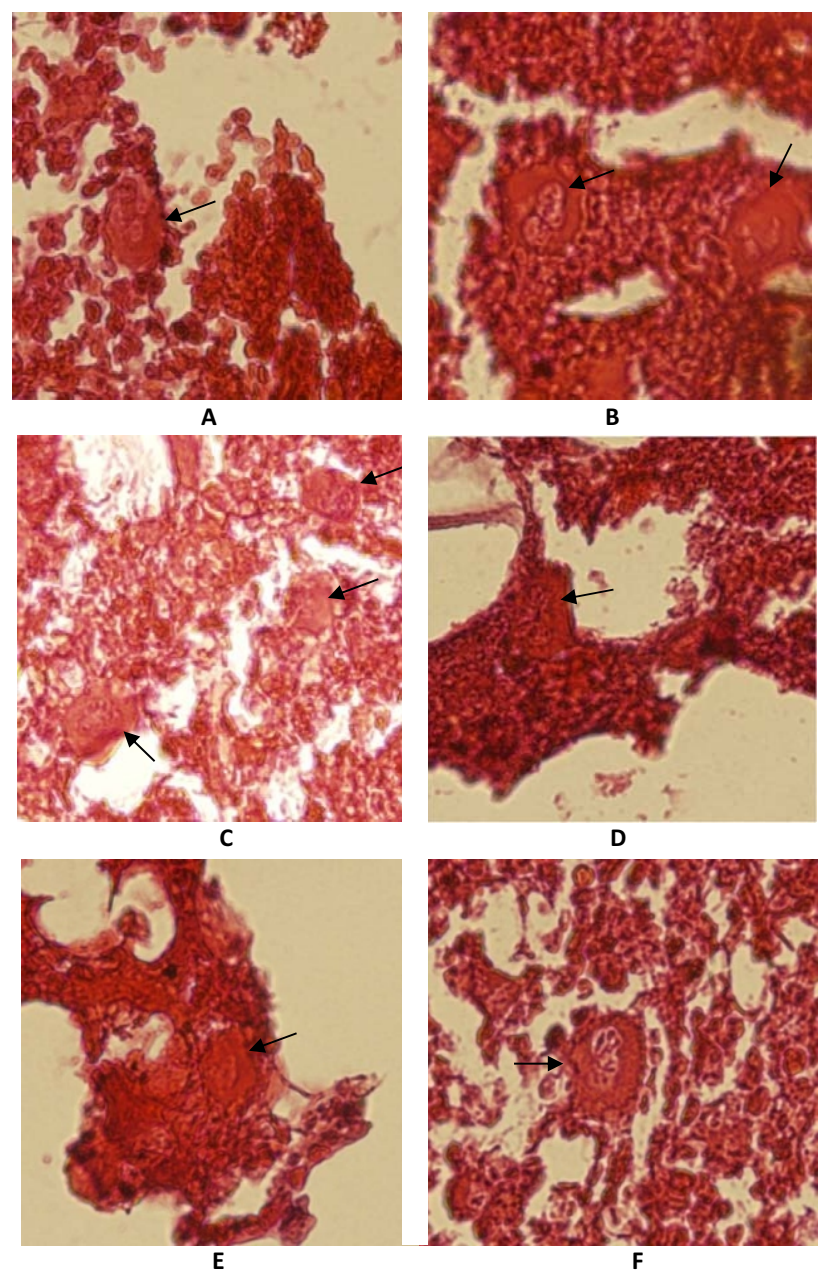

Gambar 2. Gambaran histologis perubahan jumlah osteoklast antar kelompok perlakuan

\section{Keterangan:}

Tanda panah menunjukkan sel osteoklast

A. (K-neg): kelompok tikus normal

B. (K-pos1): kelompok tikus diovarektomi dan dipertahankan selama 1 bulan

C. (K- pos2): kelompok tikus diovarektomi dan dipertahankan selama 2 bulan

D. (K-1): kelompok tikus diovarektomi dan dipertahankan selama 1 bulan + ekstrak kacang tunggak dosis $0,5 \mathrm{ml} / \mathrm{kgBB}$

E. (K-2): kelompok tikus diovarektomi dan dipertahankan selama 1 bulan + ekstrak kacang tunggak dosis $2,5 \mathrm{ml} / \mathrm{kgBB}$

F. (K-3): kelompok tikus diovarektomi dan dipertahankan selama 1 bulan + ekstrak kacang tunggak dosis $5 \mathrm{ml} / \mathrm{kgBB}$

Hasil Uji ANOVA didapatkan perbedaan signifikan jumlah osteoblas $(p=0,003)$ dan jumlah osteoklas $(p=0,002)$ antar kelompok perlakuanAnalisis Post Hoc Multiple comparison by $L S D$ menunjukkan perlakuan ovarektomi selama 1 bulan $(12,25 \pm 3,69)$ dan 2 bulan $(4,5 \pm 3,1)$ menunjukkan 
jumlah osteoblas yang lebih rendah secara signifikan dibandingkan kondisi normal $(23,25 \pm 6,59)$. Pemberian ekstrak kacang tunggak dosis $5 \mathrm{mg} / \mathrm{kgBB}$ pada tikus yang diovarektomi selama 1 bulan memberikan jumlah osteoblas yang lebih tinggi dibandingkan saat ovarektomi hingga tidak menunjukkan perbedaan signifikan kondisi normal $(19,25 \pm 9 ; p=0,329)$. Peningkatan dosis menjadi $2,5 \mathrm{mg} / \mathrm{kg}$ BB meskipun memberikan jumlah osteoblas yang lebih tinggi dibandingkan kondisi ovarektomi 1 bulan namun masih lebih rendah secara signifikan dibandingkan dengan kondisi normal $(14,25 \pm 574 ; p=0,037)$. Pada dosis tersebut kadar osteobalst lebih tinggi secara signifikan dibandingkan kondisi ovarektomi 2 bulan. Pemberian ekstrak kacang tunggak dosis $0,5 \mathrm{mg} / \mathrm{kgBB}$ pada tikus yang diovarektomi selama 2 bulan masih menunjukkan jumlah osteoblast yang lebih rendah secara signifikan normal $(9,5 \pm 2,38 ; p=0,03)$ namun lebih tinggi dibandingkan kondisi ovarektomi 2 bulan (K-pos 2).

Hasil penelitian menunjukkan perlakuan ovarektomi 1 bulan tidak memberikan perbedaan jumlah osteoklas $(7,25 \pm 2,22 ; p=0,072)$ yang signifikan dibandingkan kondisi normal (K-neg). Dengan perlakuan ovarektomi selama 2 bulan didapatkan jumlah osteoklas yang lebih tinggi $(9 \pm 1,83 ; p=0,004)$. Pemberian ekstrak kacang tunggak 0,5 $\mathrm{ml} / \mathrm{kgBB}$ pada tikus dengan ovarektomi 1 bulan, tidak menunjukkan perbedaan signifikan jumlah osteoklas $(p=1,00)$ dengan normal namun lebih rendah secara signifikan $(p=0,004)$ dibandingkan kondisi ovarektomi dua bulan. Jumlah osteoklas pada pemberian ekstrak kacang tunggak dosis $2.5 \mathrm{ml} / \mathrm{kgBB}$ pada kondisi ovarektomi 1 bulan lebih rendah secara signifikan dibandingkan kondisi ovarektomi 1 bulan $(p=0,007)$ dan dua bulan $(p=0,000)$ hingga sama dengan kondisi normal ( $p$ value $=0,267$ ). Demikian juga jumlah osteoklas pada dosis kacang tunggak $0,5 \mathrm{ml} / \mathrm{kg}$ BB pada tikus dengan ovarektomi 2 bulan lebih rendah secara signifikan dibandingkan kondisi ovarektomi 1 dan 2 bulan, bahkan sama dengan kondisi normal.

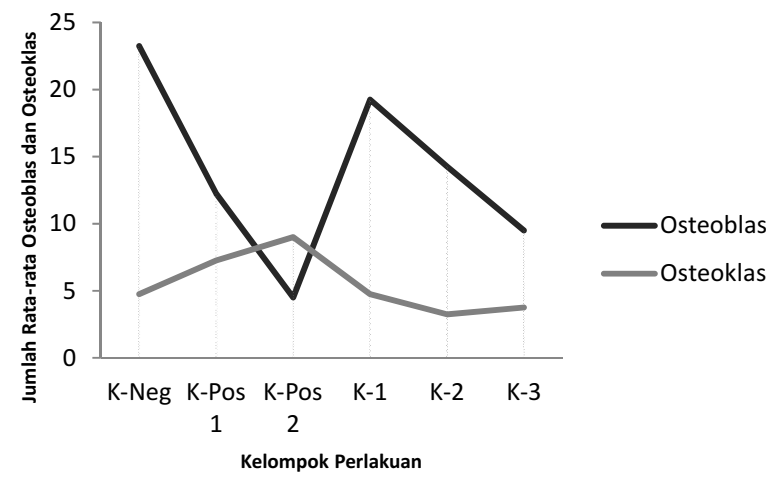

Gambar 3. Rata-rata jumlah osteoblas dan osteoklas pada femur distal per 20 lapangan pandang

\section{DISKUSI}

Secara umum hasil menunjukkan bahwa kondisi ovarektomi 1 dan 2 bulan memberikan jumlah osteoblas yang lebih kecil dibandingkan normal. Dengan pemberian ekstrak kacang tunggak dosis $0,5 \mathrm{mg} / \mathrm{kgBB}$ pada tikus yang diovarektomi 1 bulan dapat menghasilkan kadar osteoblas yang sama dengan normal. Peningkatkan dosis justru memberikan jumlah osteoblas yang lebih rendah. Pada kondisi ovarektomi 2 bulan pemberian ekstrak kacang tunggak dosis $0,5 \mathrm{mg} / \mathrm{kg}$ BB dapat menunjukkan jumlah osteoblas yang lebih tinggi dibandingkan kondisi ovarektomi namun masih lebih rendah dibandingkan normal. Hasil menunjukkan bahwa pemberian ekstrak kacang tunggak pada kondisi ovarektomi dapat memberikan jumlah osteoklas yang lebih rendah. Dosis ekstrak kacang tunggak sebesar 0,5 ml/kgBB sudah dapat memberikan jumlah osteoklas yang lebih rendah dibandingkan kondisi ovarektomi 1 dan 2 bulan hinggal mendekati kondisi normal. Dapat disimpulkan bahwa pemberian ekstrak kacang tunggak dapat mengembalikan jumlah osteoblast dan osteoklas hingga mendekati normal sesudah ovarektomi yang menggambarkan kondisi osteoporosis.

Pemberian ekstrak kacang tunggak menyebabkan peningkatan jumlah osteoblas. Peningkatan jumlah osteoblas akan memberi efek protektif untuk mencegah terjadinya osteoporosis (9). Dalam penelitian ini, diketahui bahwa dengan meningkatnya dosis membuat menurunnya jumlah osteoblas. Hal ini dikarenakan ketika kadar genistein lebih banyak, maka produksi Nitrit Oksida (NO) meningkat (10). Nitrit Oksida sebenarnya berperan penting dalam sistem imum innate, dan juga dalam pertahanan terhadap tumor dan patogen. Akan tetapi NO dalam jumlah tinggi bersifat sebagai radikal bebas yang destruktif. Nitrit Oksida dapat mempengaruhi sel untuk tetap hidup atau mati dengan menginduksi apoptosis atau malah menghambat $(11,12)$. Jumlah radikal bebas yang meningkat ini berbahaya karena radikal bebas sangat reaktif dan dapat berinteraksi dengan protein, DNA atau RNA serta mengubah fungsi mereka dan pada akhirnya mengakibatkan kematian sel (10-12). Oleh karena itu, dengan dosis ekstrak kacang tunggak yang meningkat, dapat terjadi peningkatan produksi NO yang bersifat sebagai radikal bebas yang menyebabkan kematian osteoblas.

Pemberian ekstrak kacang tunggak menyebabkan penurunan jumlah osteoklas secara bermakna. Pada Gambar 2, dengan semakin meningkatnya dosis ekstrak kacang tunggak, memang terjadi penurunan jumlah osteoklas tetapi secara statistik penurunan ini tidak berbeda bermakna. Penurunan jumlah osteoklas pada semua kelompok perlakuan menunjukkan efek protektif dari ekstrak kacang tunggak terhadap osteoporosis (9). Peningkatan dosis ekstrak kacang tunggak sampai dosis 5 $\mathrm{ml} / \mathrm{kgBB}$ tidak menyebabkan penurunan jumlah osteoklas (efek toksik) seperti yang terjadi pada osteoblas. Hal ini mungkin disebabkan osteoklas berasal dari sel mononuklear yang relatif lebih tahan terhadap radikal bebas dibanding sel biasa, sehingga meskipun kadar NO meningkat karena peningkatan dosis ekstrak kacang tunggak, kematian osteoklas tidak terjadi (13).

Pemberian ekstrak kacang tunggak dosis 0,5 ml/kgBB sanggup meningkatkan jumlah osteoblas dan menurunkan jumlah osteoklas dibandingkan kelompok kontrol positif. Pertambahan dosis ekstrak kacang tunggak ternyata malah menunjukkan penurunkan efek protektif yang diberikan oleh ekstrak kacang tunggak. Hal ini menunjukkan, ada dosis ekstrak kacang tunggak yang optimum untuk memberi efek protektif. Dosis yang 
berlebihan justru akan menimbulkan efek toksik yang menyebabkan penurunan jumlah osteoblas sehingga efek protektif ekstrak kacang tunggak menjadi tidak optimal (9).

Ekstrak kacang tunggak ditengarai mempunyai kandungan fitoestrogen yaitu genistein $(6,7)$. Fitoestrogen mempengaruhi kesehatan manusia lewat mekanisme genomic dan non genomic. Karena berat molekularnya yang rendah, fitoestrogen dapat melewati membrane sel dan berinteraksi dengan reseptor dan enzim. Mekanisme genomic termasuk efek estrogenik dan antiestrogenik pada Estrogen Receptors (ER). Mekanisme non genomic termasuk penghambatan tyrosine kinase, penghambatan DNA topoisomerase, aktivitas antioksidan, penghambatan angiogenesis, rangsangan SHBG, penghambatan $5 \alpha$ reduktase, $17 \beta-O H-$ steroid-dehydrogenase dan enzim aromatase $(6,7)$.

Secara kasar, fitoestrogen dapat diklasifikasikan dalam 3 kelas, yaitu fitoestrogen yang berinteraksi dengan ER- $\alpha$, contohnya prenylnaringenin, fitoestrogen yang berikatan dengan ER- $\beta$, contohnya genistein atau silibinin, atau yang tidak berinteraksi dengan ER- $\alpha$ maupun ER- $\beta$, contohnya adalah zearalenone (7). Fitoestrogen yang paling estrogenik adalah genistein dan metabolit daidzein, yaitu equol. Genistein menunjukkan potensi yang lebih rendah daripada estradiol, tergantung pada Estrogen Receptors (ER) mana yang berinteraksi dengannya menjadi satu per seribu ketika berinteraksi dengan ER $\alpha$ dan sepertiga ketika berinteraksi dengan ER $\beta$. Sifat estrogenik dari isoflavon disebabkan oleh cincin A-C yang menyerupai cincin $A-B$ dari estrogen dan menyerupai kelompok hidroksil dalam posisi 5, yang terlihat memainkan peranan penting dalam meningkat-

\section{DAFTAR PUSTAKA}

1. Bachmann G. Menopausal Vasomotor Symptoms: $A$ Review of Causes, Effects and Evidence-Based Treatment Options. The Journal of Reproductive Medicine. 2005; 50(3): 155-165.

2. Ferdinand Z. Osteoporosis Deteksi Dini, Penanganan, dan Terapi Praktis. Jogjakarta: Kata Hati; 2008.

3. Sutanto LB dan Sutanto DB. Menopause. Jakarta: Balai Penerbit Fakultas Kedokteran Universitas Indonesia; 2007.

4. Diel P. Phytoestrogens: Benefits and Risks for Human Health. Makalah disajikan dalam 8th Karlsruhe Nutrition Congress. Jerman, 12-14 Oktober 2003.

5. Achadiat C. Fitoestrogen untuk Wanita Menopause. (Online) 2003. http://situs.kesrepro. info/aging/jul/2003/ag01.htm.

6. Cassidy A. Potensial Risk and Benefit Phytoestrogens Rich Diets. International Journal for Vitamin and Nutrition Research. 2003; 73(2): 120-126.

7. Duffy C, Perez K, and Partridge A. Implications of Phytoestrogen Intake for Breast Cancer. A Cancer Journal for Clinicians. 2007; 57(5): 260-277.

8. Nelson HD, Humphrey LL, Nygren P, Teutsch SM, and kan aktivitas estrogen. Karena estrogenisitasnya, dalam lingkungan yang konsentrasi estrogennya rendah, individu dapat mengharapkan efek yang positif pada metabolisme tulang. Pada berbagai penelitian terhadap hewan-hewan yang sudah di ovarektomi, fitoestrogen terbukti dapat mempertahankan tulang, mengurangi kehilangan sel-sel tulang dan meningkatkan massa tulang (14).

Fitoestrogen dapat menjadi kandidat yang ideal untuk pengobatan osteoporosis karena dapat merangsang aktivitas osteoblas dan menghambat pembentukan osteoklas. Fitoestrogen merangsang osteoblas manusia untuk memproduksi OPG dan memodulasi aktivitas osteoklas, sehingga mencegah pengkroposan tulang. Dua aksi positif ini didapat pada rentang konsentrasi konsisten dengan pencernaan manusia terhadap genistein. Penemuan reseptor ER $\alpha$ dan ER $\beta$ di tulang, efek positif dari Selective estrogen receptor modulators (SERM) seperti raloxifene di hewan dan manusia, dan kenyataan bahwa terdapat kesamaan dengan raloxifene dalam membentuk ikatan dengan reseptor estrogen, fitoestrogen seperti genistein dapat mempunyai efek selektif pada tulang, memberi efek protektif terhadap fitoestrogen $(7,10)$. Efek protektif dari fitoestrogen terhadap tulang dihasilkan melalui ikatan zat ini ke reseptor estrogen dan terutama ER $\beta$. Ekspresi ER $\beta$ meningkat selama mineralisasi tulang dan afinitas tinggi dari genistein terhadap ER $\beta$ dapat membuat aksinya efisien pada level fisiologis (7).

\section{UCAPAN TERIMA KASIH}

Penulis mengucapkan terima kasih yang sebesar-besarnya kepada DR. drg. Nur Permatasari, MS yang telah membiayai dan mendukung penelitian ini sehingga penelitian ini dapat terlaksana.

Allan JD. Postmenopausal Hormone Replacement Therapy: Scientific Review. The Journal of the American Medical Association. 2002; 288(7): 872881.

9. Woolf AD and Åkesson K. Osteoporosis: An Atlas of Investigation and Diagnosis. Oxford: Clinical Publishing; 2008.

10. Wang X, Chen S, Ma G, Ye M and Lu G. Genistein Protects Dopaminergic Neurons by Inhibiting Microgliai Activation. Neuroreport. 2005; 16(3): 267270.

11. Brüne B, Knethen A, and Sandau KB. Nitric Oxide (NO): an Effector of Apoptosis. Call Death and Differentiation. 1999; 6(10): 969-975.

12. Brüne, B. Nitric Oxide: NO Apoptosis or Turning it ON? Cell Death \& Differentiation. 2003; 10(8): 864-869.

13. Laochumroonvorapong P, Paul S, Elkon KB, and Kaplan G. H2O2 Induces Monocyte Apoptosis and Reduces Viability of Mycobacterium avium-M. Intracellulare within Cultured Human Monocytes. Infection and Immunity. 1996; 64(2):452-459.

14. Lauritzen C and Studd J. Current Management of the Menopause. United Kingdom: Taylor \& Francis Group: 2005. 